\title{
Het kind met (te) laag gewicht
}

\section{WAT IS HET PROBLEEM?}

Wanneer ouders de huisarts consulteren over hun kind met een (te) laag gewicht, staat de huisarts voor de uitdaging in relatief korte tijd een inschatting te maken van mogelijk ondergewicht en mogelijke oorzaken. Een te laag gewicht kan een uiting zijn van een slechte voedingstoestand als gevolg van een eet- of voedingsprobleem door een lichamelijke oorzaak. Een slechte voedingstoestand kan ook niet-somatische oorzaken hebben.

\section{WAT MOET IK WETEN?}

Een te laag gewicht kan een uiting zijn van ondervoeding. De NVK (Nederlandse Vereniging voor Kindergeneeskunde) definieert ondervoeding als een acute of chronische toestand waarbij een tekort of disbalans van energie, eiwit en andere voedingsstoffen leidt tot meetbare, nadelige effecten op lichaamssamenstelling, functioneren en klinische resultaten.

Er is sprake van acute ondervoeding als het gewicht meer dan 2 SD onder het gemiddelde ligt bij een normale lengte of als er een significante afbuiging is in gewichtsgroei in korte tijd. Men spreekt van chronische ondervoeding bij een achterstand in de lengtegroei waarbij de SD-score voor lengte naar leeftijd meer dan 2 SD onder het gemiddelde ligt of wanneer er een significante afbuiging is in lengtegroei. Kinderen met een chronische ondervoeding zijn vaak te licht en te klein voor hun leeftijd. Maar hun gewicht naar lengte is vaak wel normaal. ${ }^{1}$

Bij gezonde, normaal ontwikkelende jonge kinderen komen lichte tot matige voedingsproblemen frequent voor (25$45 \%$. Veel jonge kinderen zijn in periodes selectief bij het eten en ze kunnen sterk wisselen in voedselinname. Deze periodes gaan doorgaans vanzelf over. Bij kinderen met een psychomotorische retardatie of kinderen met een chronische ziekte komen voedingsproblemen veel vaker voor (40-80\%). Prematuren, kinderen met een langdurige ziekenhuisopname en kinderen die op jonge leeftijd ernstig ziek zijn geweest hebben een verhoogd risico op een ernstig voedingsprobleem. Het is onbekend hoe vaak eetproblemen op de basisschoolleeftijd voorkomen. Wel zijn er aanwijzingen dat eetstoornissen als anorexia en boulimia al bij kinderen tussen 8 en 12 jaar kunnen voorkomen. ${ }^{2}$

\section{WAT MOET IK DOEN?}

De huisarts moet beoordelen of het kind ondervoed is. Tijdens de anamnese vraagt de huisarts naar gegevens over de groei en het gewicht. Bij jonge kinderen kan gevraagd worden naar het groeiboekje. Ook moet de huisarts vragen naar klachten van onderliggende ziekte die kunnen leiden tot een verminderde intake of een verhoogd verbruik/verlies. Informatie over de ontwikkeling en het activiteitenpatroon van het kind kan ook verder inzicht verschaffen.

Bij het lichamelijk onderzoek is het lichaamsgewicht de belangrijkste parameter om acute ondervoeding vast te stellen. Wanneer er twijfel is over de lengte (bijvoorbeeld doordat er geen recent meetmoment bij het consultatiebureau of de schoolarts is), meet en noteert de huisarts deze. Zowel gewichtsverlies als niet aankomen in gewicht, als stilstand van de groei, zijn goede indicatoren van een verslechtering van de voedingstoestand. Eventueel kan de groei in een groeicurve uitgezet worden. Groeicurves voor de Nederlandse populatie zijn te vinden op de website van TNO. ${ }^{3}$ Daar staat ook een BMImeter voor kinderen met een klasse-verdeling voor over- en ondergewicht.

Bij het lichamelijk onderzoek schat de huisarts de voedingstoestand globaal in. Daartoe is het belangrijk te kijken of er verlies is van subcutaan vet, er een ingevallen gelaat is of verlies van spiermassa. Ook de algemene indruk van het kind (ziek, niet-ziek), de spierkracht en de conditie van huid en haar kunnen bijdragen aan de beoordeling van de voedingstoestand. Daarnaast kan de huisarts kijken naar objectiveerbare symptomen van een eventuele onderliggende ziekte.

Als er een mild, mogelijke voorbijgaand voedingsprobleem is dat weinig effect heeft op de voedingstoestand, kan de huisarts het kind zelf volgen. Bij vragen over eetgedrag kan de huisarts eventueel verwijzen naar het Centrum voor Jeugd en Gezin of naar een orthopedagoog of kinderpsycholoog. De huisarts verwijst het kind naar de kinderarts bij aanwijzingen van onderliggende pathologie die de huisarts niet kan behandelen, bij afbuigende groei of bij een verslechterende voedingstoestand.

\section{WAT MOET IK UITLEGGEN?}

Een laag gewicht bij een kind kan een uiting zijn van ondervoeding. Bij jonge kinderen komen regelmatig periodes voor van verminderde inname die kunnen leiden tot een laag gewicht. Doorgaans gaan deze periodes vanzelf over. Wanneer het kind niet goed groeit of er andere klachten zijn kan de huisarts het kind verwijzen.

\section{LITERATUUR}

1 NVK Richtlijn Signalering van somatische oorzaken van afwijkend voedingsgedrag bij kinderen versie 12 dd 02 mei 2012

2 CBO Richtlijn Eetstoornissen, 2006.

3 TNO groeicurven. www.tno.nl/nl/aandachtsgebieden/gezond-leven/prevention-work-health/gezond-en-veilig-opgroeien/groeidiagrammen-inpdf-formaat. 